\title{
The pathogenesis of HIV infection: stupid may not be so dumb after all Stephen M Smith*
}

Address: Saint Michael's Medical Center and The New Jersey Medical School, Newark New Jersey 07102, USA

Email: Stephen M Smith* - ssmith1824@aol.com

* Corresponding author

\section{Published: 8 September 2006}

Retrovirology 2006, 3:60 doi:10.1 186/1742-4690-3-60

This article is available from: http://www.retrovirology.com/content/3/l/60

(c) 2006 Smith; licensee BioMed Central Ltd.

This is an Open Access article distributed under the terms of the Creative Commons Attribution License (http://creativecommons.org/licenses/by/2.0), which permits unrestricted use, distribution, and reproduction in any medium, provided the original work is properly cited.
Received: 15 August 2006

Accepted: 8 September 2006

\begin{abstract}
In the mid-1990's, researchers hypothesized, based on new viral load data, that HIV-I causes CD4' T-cell depletion by direct cytopathic effect. New data from non-human primate studies has raised doubts about this model of HIV-I pathogenesis. Despite having high levels of viremia, most SIV infections are well tolerated by their natural hosts. Two recent studies of these models provide information, which may be useful in determining how HIV-I causes CD4 ${ }^{+}$T-cell loss. A full understanding of pathogenesis may lead to novel therapies, which preserve the immune system without blocking virus replication.
\end{abstract}

\section{Discussion}

HIV-1 infection is characterized by an insidious deterioration of the cellular immune system[1]. Both the quantity and proportion of plasma CD4+ T-cells decrease steadily over a period of years to decades, and this progressive loss of $\mathrm{CD} 4^{+} \mathrm{T}$-cells is associated with the development of acquired immunodeficiency syndrome (AIDS) in infected individuals. The degree of immunodeficiency associated with HIV-1 infection, as defined by the onset of opportunistic diseases, correlates closely with plasma CD4 ${ }^{+} \mathrm{T}$-cell counts. Moreover, the rate at which immunosuppression develops also closely reflects the levels of HIV-1 RNA in plasma, such that the higher the HIV-1 viral load, the greater the loss of circulating $\mathrm{CD}_{4}{ }^{+} \mathrm{T}$-cells per year. A decade ago, researchers believed that the $\mathrm{CD}^{+}{ }^{+} \mathrm{T}$-cell depletion seen in the plasma compartment was reflective of the total CD4 ${ }^{+} \mathrm{T}$-cell pool and that virus replication was driving the slow loss of cells[2]. The seemingly direct relationship of HIV-1 replication with systemic CD4+ $\mathrm{T}$ cell loss and immunosuppression was made famous by the quote "It's the virus, stupid[3]", a humorous but pointed reference to the apparent "cause-and-effect" nature of this con- nection. Over the past few years, in light of new data, experts are now questioning this hypothesis.

It is now widely appreciated that both HIV-1 infection in humans, and simian immunodeficiency virus (SIV) infection in rhesus macaques (Macaca mulatta), are associated with destruction of the vast majority of memory $\mathrm{CD} 44^{+} \mathrm{T}$ cells in the gastrointestinal tract in the first few weeks after infection [4-13]. Although mucosal tissues harbor a large percentage of the total $\mathrm{CD} 4^{+} \mathrm{T}$-cell population, this profound destruction is not reflected in the plasma cell pool. The depleted, mucosal CD4+ $4^{+}$-cells are not completely replaced and the host remains deficient in memory CD4+ T-cells. Some speculate that the GI tract is not unique and that a widespread mucosal immunodeficiency occurs very early after infection. In this altered state, the mucosal lymphocytes do not appropriately or adequately control invading organisms. This lack of control then contributes to a more generalized activation of the immune system, which is seen during the chronic phase of HIV-1 infection [14]. The level of immune system activation correlates with viral load and independently with the rate of $\mathrm{CD} 4^{+}$ T-cell depletion. Of the many activation markers, the pres- 
ence of increased CD38 on CD8+ T-cells correlates best with the rate of disease progression[15,16]. Many now believe chronic immune activation, not simply HIV-1 replication, leads to progressive depletion of the remaining CD4+ T-cells.

Much of the new data in support of this concept comes from non-human primate models of HIV infection. More than 30 monkeys and apes are naturally infected with distinct strains of SIV [17], and most of these viruses are well tolerated by their natural hosts. As a case in point, both sooty mangabeys (Cercocebus torquatus atys) and African green monkeys (Chlorocebus spp.) are the natural hosts for SIVsmm and SIVagm, respectively. In each case, SIV replicates to high levels, but the virus does not cause circulating $\mathrm{CD} 4+$ T-cell lymphopenia or immunodeficiency. However, experimental infection of rhesus macaques with SIVsmm, or other closely related strains of SIV, does cause a disease very similar to AIDS. Investigators have been trying to understand why SIV infection causes disease in some monkeys, but not others, as a means of unraveling the basis for immunodeficiency in humans infected with HIV-1. Reports from two recent studies now shed light on this paradox.

In the June issue of Cell, Schindler et al. report that nef, which is present in all primate lentiviruses, may protect the natural host by modulating expression of the T-cell receptor-CD3 complex (TCR-CD3)[18]. Nef is a small lentiviral protein with many attributed functions, including down regulation of CD4, CD28, and MHC-I. The authors analyzed 30 nef alleles from 30 different primate lentiviruses. All of the nef alleles down regulated CD4 and MHCI molecules from the cell surface. Most also down regulated TCR-CD3 efficiently. However some, including those of HIV-1 and SIVcpz (a close relative of HIV-1), had no effect on TCR-CD3 cell surface expression [see Figure 1]. T-cells expressing nef alleles that were able to down modulate TCR-CD3 had decreased levels of activation after PHA stimulation. Further, expression of these nef alleles in peripheral blood mononuclear cells (PBMC) protected the cells against PHA-induced apoptosis. In contrast, those nef alleles that did not reduce cell surface expression of TCR-CD3 were found to increase T-cell activation and apoptosis.

The authors noted that the TCR-CD3-downmodulating nefs belong to viruses such as SIVsmm that do not cause disease in their natural hosts. This newly described activity of nef may be linked with the maintenance of an intact immune system in SIVsmm-infected sooty mangabeys. SIV plasma levels in sooty mangabeys typically exceed those of HIV-1 in humans [19-21]. Yet, sooty mangabeys do not develop immunodeficiency. By comparison, HIV1 nef does not affect the TCR-CD3 complex and this may, in turn, contribute to aberrant activation of the immune system and the gradual erosion of immune function associated with AIDS.

Many questions remain regarding this hypothesis. In the chronic phase of infection, HIV-1 infects only a small minority $(<1.0 \%)$ of $\mathrm{CD}^{+}{ }^{+} \mathrm{T}$-cells [22], yet a much higher percentage of many different cell types possess the activated phenotype [23]. How does increased activation or apoptosis of a small percentage of $\mathrm{CD}^{+}{ }^{+} \mathrm{T}$-cells (those infected with HIV-1) lead to activation of large populations of uninfected cells? Like HIV-1 nef, the nef gene of SIVcpz also does not down regulate the TCR-CD3 complex, and yet most chimpanzees infected with SIVcpz do not develop immune system activation or $\mathrm{CD} 4^{+} \mathrm{T}$-cell lymphopenia [24][25][26][27]. As discussed in the Cell article, SIVmac nef has TCR-CD3 down-regulating activity. If so, why do SIVmac-infected rhesus macaques have highly activated immune systems? Finally, what is the evolutionary advantage of HIV-1 without this activity? If the virus, which decreases TCR-CD3 expression, can replicate to high levels, how does the loss of this function of $n e f$ make HIV-1 more fit? Future studies are clearly needed to address these questions.

Another study of relevance to this topic was recently published in Retrovirology[28]. Ploquin et al. compared the non-pathogenic SIVagm infection of African green monkeys with the virulent infection of rhesus macaques with SIVmac. The authors measured both pro-(TNF- $\alpha$ and IFN$\gamma)$ and anti-(IL-10) inflammatory cytokines after in vivo infection. The levels of TNF- $\alpha$ and IFN- $\gamma$ transcripts in PBMC increased significantly in rhesus macaques in the first two weeks of infection with SIVmac. In contrast, TNF$\alpha$ and IFN- $\gamma$ expression did not change during this time in African green monkeys infected with SIVagm. Differences were also noted in expression of IL-10, a negative regulator of inflammation, which increased in the African green monkeys at days 10-16 post-infection, but was not upregulated in SIVmac-infected macaques. The authors found that $\operatorname{smad} 4$, a key intracellular, downstream signal of TGF $\beta-1$ binding, was also up-regulated in infected African green monkeys. TGF $\beta-1$ is an important, anti-inflammatory cytokine and these data support the hypothesis that a pro-inflammatory state is associated with pathogenic SIV infection.

Each of these new articles strongly supports the concept that immune activation, at least in part, drives $\mathrm{CD} 44^{+} \mathrm{T}$-cell depletion, whereas viremia alone is not sufficient to cause clinically significant immunodeficiency. When generalized immune system activation and viremia appear together, as in the case of HIV-infected humans and SIVinfected macaques, disease occurs. Modulation of TCRCD3 may help prevent activation of the immune system 


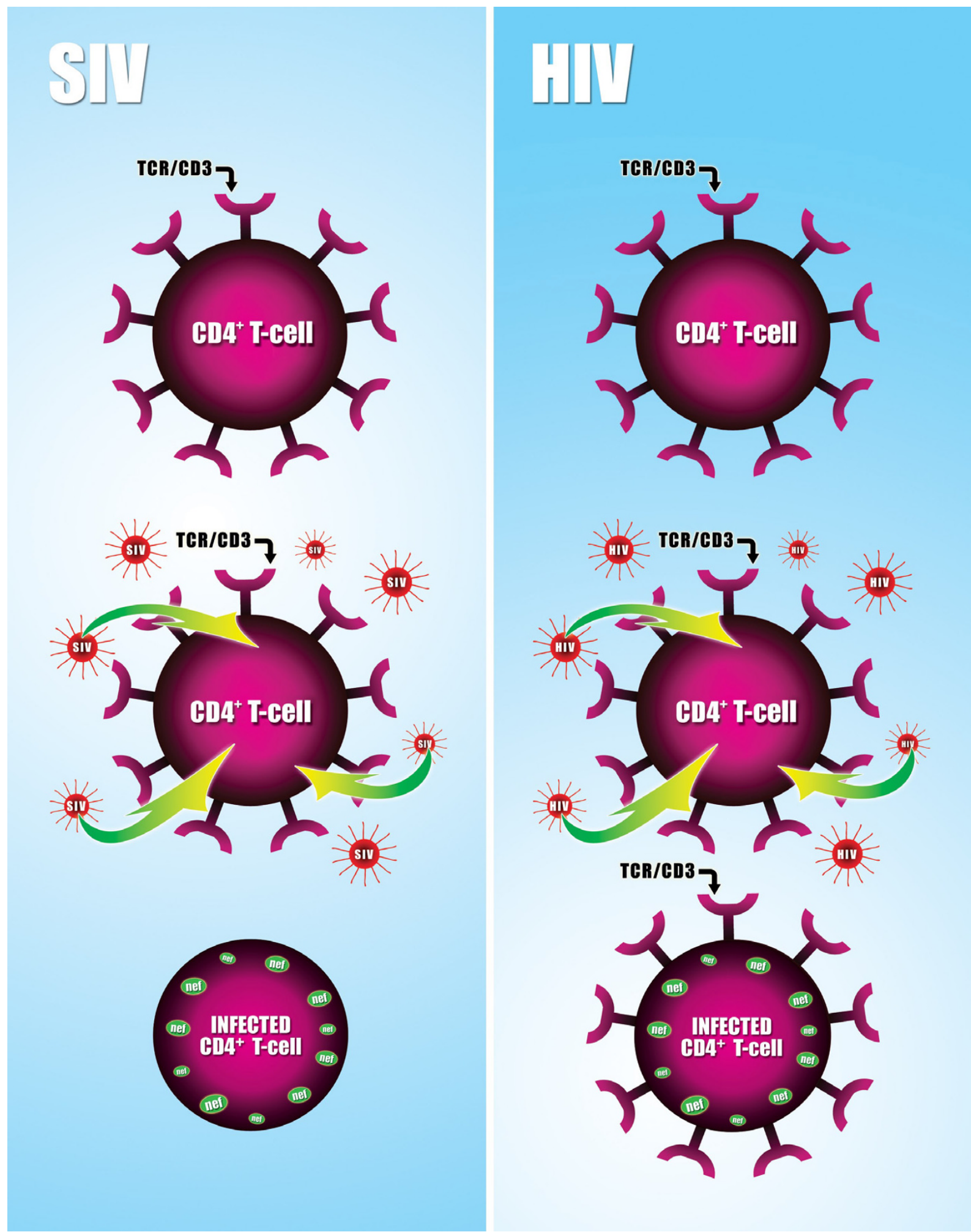

Figure I

SIV (left panel) and HIV (right panel) infected CD4+ T-lymphocytes. Following infection, each produces Nef, which associates with the cell membrane. However, only SIV Nef downregulates the T-cell receptor complex (TCR). HIV infected cells still express the TCR and are more prone to activation and apoptosis. 
in non-pathogenic infections, while localized CD4+T-cell depletion at the mucosal surfaces may allow antigenic stimulation and activation of the remaining cells. Proinflammatory cytokines are also likely to play a role: $\mathrm{CD}^{+}$ T-cells are activated and not infected with HIV/SIV, B-cells and NK cells are also activated. The level of immune activation drastically decreases with effective HIV therapy [29][30][31][32][33][34]. However, cellular activation markers do not return to normal levels even when viremia is undetectable. In most HIV-positive patients, viral suppression leads to large increases in their plasma $\mathrm{CD}^{+}{ }^{+} \mathrm{T}-$ cell counts. Those with little or no change in their CD4 ${ }^{+} \mathrm{T}-$ cell counts generally have persistent immune system activation [35].

Using non-human primate models, researchers hope to delineate the HIV-induced immune activation pathways. Such a discovery could lead to innovative new therapies that specifically block activation of the immune system. While inhibiting HIV-1 replication during chronic infection makes sense, it is not the true goal of HIV treatment. We treat HIV to prevent or slow the development of immunodeficiency. A therapy that preserves the immune system without inhibiting virus replication would certainly be a welcome addition to currently available antiretroviral drugs that target HIV but do not adequately restore immune function.

\section{References}

I. Vergis EN, Mellors JW: Natural history of HIV-I infection. Infect Dis Clin North Am 2000, 14:809-825. v-vi

2. Ho DD, Neumann AU, Perelson AS, Chen W, Leonard JM, Markowitz $M$ : Rapid turnover of plasma virions and CD4 lymphocytes in HIV-I infection. Nature 1995, 373:123-I26.

3. Cohen J: AIDS research. Keystone's blunt message: 'it's the virus, stupid'. Science 1993, 260:292-293.

4. Brenchley JM, Schacker TW, Ruff LE, Price DA, Taylor JH, Beilman GJ, Nguyen PL, Khoruts A, Larson M, Haase AT, Douek DC: CD4+ T cell depletion during all stages of HIV disease occurs predominantly in the gastrointestinal tract. J Exp Med 2004, 200:749-759.

5. Guadalupe M, Reay E, Sankaran S, Prindiville T, Flamm J, McNeil A, Dandekar S: Severe CD4+ T-cell depletion in gut lymphoid tissue during primary human immunodeficiency virus type I infection and substantial delay in restoration following highly active antiretroviral therapy. J Virol 2003, 77: I I708-II7I7.

6. Li Q, Duan L, Estes JD, Ma ZM, Rourke T, Wang Y, Reilly C, Carlis J, Miller CJ, Haase AT: Peak SIV replication in resting memory CD4+ $T$ cells depletes gut lamina propria CD4+ $T$ cells. Nature 2005, 434: I |48-II52.

7. Mattapallil JJ, Douek DC, Hill B, Nishimura Y, Martin M, Roederer M: Massive infection and loss of memory CD4+ $T$ cells in multiple tissues during acute SIV infection. Nature 2005, 434: $1093-1097$.

8. Mehandru S, Poles MA, Tenner-Racz K, Horowitz A, Hurley A, Hogan C, Boden D, Racz P, Markowitz M: Primary HIV-I infection is associated with preferential depletion of CD4+ $T$ lymphocytes from effector sites in the gastrointestinal tract. J Exp Med 2004, 200:76 I-770.

9. Sankaran S, Guadalupe M, Reay E, George MD, Flamm J, Prindiville T, Dandekar S: Gut mucosal $\mathbf{T}$ cell responses and gene expression correlate with protection against disease in long-term HIV-I-infected nonprogressors. Proc Natl Acad Sci USA 2005, I 02:9860-9865.
10. Veazey R, Lackner A: The mucosal immune system and HIV-I infection. AIDS Rev 2003, 5:245-252.

II. Veazey RS, DeMaria M, Chalifoux LV, Shvetz DE, Pauley DR, Knight $\mathrm{HL}$, Rosenzweig M, Johnson RP, Desrosiers RC, Lackner AA: Gastrointestinal tract as a major site of CD4+ $T$ cell depletion and viral replication in SIV infection. Science 1998, 280:427-43I.

12. Veazey RS, Mansfield KG, Tham IC, Carville AC, Shvetz DE, Forand AE, Lackner AA: Dynamics of CCR5 expression by CD4(+) T cells in lymphoid tissues during simian immunodeficiency virus infection. J Virol 2000, 74: I I00 I-I I007.

13. Veazey RS, Tham IC, Mansfield KG, DeMaria M, Forand AE, Shvetz DE, Chalifoux LV, Sehgal PK, Lackner AA: Identifying the target cell in primary simian immunodeficiency virus (SIV) infection: highly activated memory CD4(+) $T$ cells are rapidly eliminated in early SIV infection in vivo. J Virol 2000, 74:57-64.

14. Brenchley JM, Price DA, Douek DC: HIV disease: fallout from a mucosal catastrophe? Nat Immunol 2006, 7:235-239.

15. Liu Z, Cumberland WG, Hultin LE, Kaplan AH, Detels R, Giorgi JV: CD8+ T-lymphocyte activation in HIV-I disease reflects an aspect of pathogenesis distinct from viral burden and immunodeficiency. J Acquir Immune Defic Syndr Hum Retrovirol 1998, I 8:332-340.

16. Liu Z, Cumberland WG, Hultin LE, Prince HE, Detels R, Giorgi JV: Elevated CD38 antigen expression on CD8+ $T$ cells is a stronger marker for the risk of chronic HIV disease progression to AIDS and death in the Multicenter AIDS Cohort Study than CD4+ cell count, soluble immune activation markers, or combinations of HLA-DR and CD38 expression. J Acquir Immune Defic Syndr Hum Retrovirol 1997, I 6:83-92.

17. Apetrei C, Marx PA: African lentiviruses related to HIV. J Neurovirol 2005, I I (Suppl I):33-49.

18. Schindler M, Munch J, Kutsch O, Li H, Santiago ML, Bibollet-Ruche F, Muller-Trutwin MC, Novembre FJ, Peeters M, Courgnaud V, Bailes E, Roques P, Sodora DL, Silvestri G, Sharp PM, Hahn BH, Kirchhoff F: Nef-mediated suppression of $T$ cell activation was lost in a lentiviral lineage that gave rise to HIV-I. Cell 2006, I 25: 1055-1067.

19. Chakrabarti LA: The paradox of simian immunodeficiency virus infection in sooty mangabeys: active viral replication without disease progression. Front Biosci 2004, 9:52 I-539.

20. Kaur A, Grant RM, Means RE, McClure H, Feinberg M, Johnson RP: Diverse host responses and outcomes following simian immunodeficiency virus SIVmac239 infection in sooty mangabeys and rhesus macaques. I Virol 1998, 72:9597-96 II.

2I. Rey-Cuille MA, Berthier JL, Bomsel-Demontoy MC, Chaduc Y, Montagnier L, Hovanessian AG, Chakrabarti LA: Simian immunodeficiency virus replicates to high levels in sooty mangabeys without inducing disease. J Virol 1998, 72:3872-3886.

22. Brenchley JM, Hill BJ, Ambrozak DR, Price DA, Guenaga FJ, Casazza JP, Kuruppu J, Yazdani J, Migueles SA, Connors M, Roederer M, Douek DC, Koup RA: T-cell subsets that harbor human immunodeficiency virus (HIV) in vivo: implications for HIV pathogenesis. J Virol 2004, 78: I I60-I I68.

23. Deeks SG, Hoh R, Grant RM, Wrin T, Barbour JD, Narvaez A, Cesar D, Abe K, Hanley MB, Hellmann NS, Petropoulos CJ, McCune JM, Hellerstein MK: CD4+ $T$ cell kinetics and activation in human immunodeficiency virus-infected patients who remain viremic despite long-term treatment with protease inhibitor-based therapy. J Infect Dis 2002, I 85:315-323.

24. Gougeon ML, Garcia S, Heeney J, Tschopp R, Lecoeur H, Guetard D, Rame V, Dauguet C, Montagnier L: Programmed cell death in AIDS-related HIV and SIV infections. AIDS Res Hum Retroviruses 1993, 9:553-563.

25. Gougeon ML, Lecoeur H, Boudet F, Ledru E, Marzabal S, Boullier S, Roue R, Nagata S, Heeney J: Lack of chronic immune activation in HIV-infected chimpanzees correlates with the resistance of $\mathrm{T}$ cells to Fas/Apo-I (CD95)-induced apoptosis and preservation of a $\mathbf{T}$ helper I phenotype. J Immunol I997, I 58:2964-2976.

26. Heeney J, Jonker R, Koornstra W, Dubbes R, Niphuis H, Di Rienzo AM, Gougeon ML, Montagnier L: The resistance of HIV-infected chimpanzees to progression to AIDS correlates with absence of HIV-related T-cell dysfunction. J Med Primatol 1993, 22:194-200. 
27. Heeney JL, Rutjens E, Verschoor EJ, Niphuis $H$, ten Haaft $P$, Rouse $S$, McClure H, Balla-Jhagjhoorsingh S, Bogers W, Salas M, Cobb K, Kestens L, Davis D, van der Groen G, Courgnaud V, Peeters M, Murthy KK: Transmission of simian immunodeficiency virus SIVcpz and the evolution of infection in the presence and absence of concurrent human immunodeficiency virus type $I$ infection in chimpanzees. J Virol 2006, 80:7208-72।8.

28. Ploquin MJ, Desoutter JF, Santos PR, Pandrea I, Diop OM, Hosmalin A, Butor C, Barre-Sinoussi F, Muller-Trutwin MC: Distinct Expression Profiles of TGF-beta I Signaling Mediators in pathogenic SIVmac and non-pathogenic SIVagm Infections. Retrovirology 2006, 3:37.

29. Giorgi JV, Hultin LE, McKeating JA, Johnson TD, Owens B, Jacobson LP, Shih R, Lewis J, Wiley DJ, Phair JP, Wolinsky SM, Detels R: Shorter survival in advanced human immunodeficiency virus type I infection is more closely associated with T lymphocyte activation than with plasma virus burden or virus chemokine coreceptor usage. J Infect Dis 1999, 179:859-870.

30. Giorgi JV, Lyles RH, Matud JL, Yamashita TE, Mellors JW, Hultin LE, Jamieson BD, Margolick JB, Rinaldo CR Jr, Phair JP, Detels R: Predictive value of immunologic and virologic markers after long or short duration of HIV-I infection. J Acquir Immune Defic Syndr 2002, 29:346-355.

31. Giorgi JV, Majchrowicz MA, Johnson TD, Hultin P, Matud J, Detels R: Immunologic effects of combined protease inhibitor and reverse transcriptase inhibitor therapy in previously treated chronic HIV-I infection. Aids 1998, I 2: 1833-1844.

32. Hazenberg MD, Otto SA, van Benthem BH, Roos MT, Coutinho RA, Lange JM, Hamann D, Prins M, Miedema F: Persistent immune activation in HIV-I infection is associated with progression to AIDS. Aids 2003, 17:188|-1888.

33. Hazenberg MD, Stuart JW, Otto SA, Borleffs JC, Boucher CA, de Boer RJ, Miedema F, Hamann D: T-cell division in human immunodeficiency virus (HIV)-I infection is mainly due to immune activation: a longitudinal analysis in patients before and during highly active antiretroviral therapy (HAART). Blood 2000, 95:249-255.

34. Lederman MM, Connick E, Landay A, Kuritzkes DR, Spritzler J, St Clair M, Kotzin BL, Fox L, Chiozzi MH, Leonard JM, Rousseau F, Wade M, Roe JD, Martinez A, Kessler H: Immunologic responses associated with 12 weeks of combination antiretroviral therapy consisting of zidovudine, lamivudine, and ritonavir: results of AIDS Clinical Trials Group Protocol 315. J Infect Dis 1998, 178:70-79.

35. Anthony KB, Yoder C, Metcalf JA, DerSimonian R, Orenstein JM, Stevens RA, Falloon J, Polis MA, Lane HC, Sereti I: Incomplete CD4 T cell recovery in HIV-I infection after 12 months of highly active antiretroviral therapy is associated with ongoing increased CD4 T cell activation and turnover. J Acquir Immune Defic Syndr 2003, 33:125-133.

Publish with Bio Med Central and every scientist can read your work free of charge

"BioMed Central will be the most significant development for disseminating the results of biomedical research in our lifetime. "

Sir Paul Nurse, Cancer Research UK

Your research papers will be:

- available free of charge to the entire biomedical community

- peer reviewed and published immediately upon acceptance

- cited in PubMed and archived on PubMed Central

- yours - you keep the copyright
BioMedcentral 